\title{
The New Type of Agricultural Management Main Body and Its Education and Training Mode in the Rural Rejuvenation Period
}

\author{
Ajun Wan ${ }^{1,}$, Zhi Ang Zhang ${ }^{2}$ \\ ${ }^{1}$ Ajun Wan, male, New Rural Development Research Institute of Tongji University, Shanghai, China, mainly engaged in research on \\ environmental value-added and agricultural resources; \\ ${ }^{2}$ ZhiAng Zhang, male, School of Electronics and Information Engineering, Tongji University, Shanghai, China, mainly engaged in \\ research on agricultural facilities and planning
}

\begin{abstract}
The modern agricultural industrial system composed of new agricultural management entities is the main force for rural revitalization. However, the research on the main body of new agricultural management is still in its infancy. This paper summarizes the existing problems of the new type of agricultural main body through a comprehensive summary and analysis of the research on the concept, type, characteristics and training mode of the new type of agricultural main body. At the same time, it summarizes the cultivation model of new agricultural management from the perspective of type and specialty. The new type of agricultural business entities can provide a guarantee foundation for the direction of large-scale mechanization of agricultural development in the future, expand the channels for agricultural entities to obtain information, and play the role of information resource allocation.
\end{abstract}

\section{Introduction}

Since the Central Rural Work Conference in December 2017 proposed a national strategy for rural revitalization, at present, agricultural technology promotion has applied modern science and technology to agricultural production, which has become an effective way to help farmers increase production and income, and achieve agricultural modernization. My country's traditional agriculture is gradually transitioning to modern agriculture, and it has entered a new historical period, and new business forms and new business entities have emerged.Traditional smallholders are not highly mechanized, with low labor efficiency and serious fragmentation, which cannot adapt to the future development direction of large-scale mechanized agriculture.

On the one hand, The main body of operation is an important carrier and policy grasp of "Internet + modern agriculture". On the other hand, "Internet + modern agriculture" is an important direction and basic approach for the cultivation and development of new agricultural management entities. In this regard, the National Bureau of Statistics has made important contributions to the Sustainable Development of Rural Economy (2019) and the "Analysis Report on the Development of China's New Type Agricultural Business Entities 2019".The Sustainable Development of Rural Economy (2019) of the National Bureau of Statistics has constructed China's agricultural and rural development from five aspects: infrastructure, agricultural production, industrial institutions, and residents' income, and used various indexes to compare the development of modernization in recent years.However, this content is only an overview of the production of agricultural entities, not an analysis of the cultivation of agricultural entities, and the differences in the new informatization of planting production. Therefore, it is necessary to conduct special research on the cultivation of new agricultural business entities in China.

Under such circumstances, it is of great significance to study and judge the current development of new agricultural business entities in rural areas, adjust corresponding education and training models and methods, promote new agricultural entities to master the technology of large-scale mechanization development and accelerate the promotion of "Internet + modern agriculture".In view of this, this article will conduct a more comprehensive summary and analysis of the new agricultural management entities, and try to sort out the new education and training model. Research and analysis of new agricultural business entities can develop a new development software for the education and training of agricultural business entities. The education and training of new agricultural management entities can make the new agricultural management entities professional and management-oriented for future agriculture. The direction of development of scale and mechanization has laid a solid foundation.

Compared with previous studies, the research contributions of this article are mainly three points: First, the analysis objects of this article cover five types of new agricultural business entities-professional large households, family farms, leading agricultural enterprises,

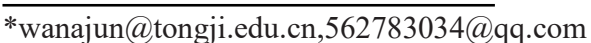


farmer cooperatives and agricultural socialized services for training and education models Construct and cultivate separately at different levels.Second, the emergence of "Internet + modern agriculture" is the trend of large-scale agricultural development. From the stage of production and planting to market sales, specialized talents are needed for operation and management, and agricultural technical talents who are specialized, understand operation, and manage well are needed.Third, "Internet + modern agriculture" shortens the distance limit, saves time and costs, and conducts professional and technical learning all the time and anywhere. The above three characteristics can make the analysis results of this article deeper than previous studies to deepen the overall understanding of the cultivation and development status and existing problems of the new agricultural business entities nationwide.

\section{New agricultural management entities}

\subsection{Types of new agricultural management entities}

The new type of agricultural management entity refers to a large-scale operation, knowing technology, capable of

Table 1 Type comparison of new agricultural management entities

\begin{tabular}{|c|c|c|c|c|c|}
\hline & Professional major & family farm & $\begin{array}{c}\text { Farmers } \\
\text { Cooperative }\end{array}$ & $\begin{array}{c}\text { Leading agricultural } \\
\text { enterprise }\end{array}$ & $\begin{array}{c}\text { Agricultural } \\
\text { Socialization Service }\end{array}$ \\
\hline Business model & $20-50$ acres & $20-50$ acres & 2.1-2.2 million & $>500$ acres & $\begin{array}{c}\text { Government-led } \\
\text { collective economic } \\
\text { organizations }\end{array}$ \\
\hline Source of labor & $\begin{array}{l}\text { Mainly self- } \\
\text { employed }\end{array}$ & $\begin{array}{l}\text { Mainly self-owned } \\
\text { labor, supplemented } \\
\text { by hired labor }\end{array}$ & $\begin{array}{c}\text { Mainly family } \\
\text { management, joint } \\
\text { organizations } \\
\text { engaged in specific } \\
\text { economic activities }\end{array}$ & $\begin{array}{l}\text { Mainly hired labor, } \\
\text { less own labor }\end{array}$ & $\begin{array}{c}\text { Mainly based on } \\
\text { own labor, } \\
\text { Supplementary labor }\end{array}$ \\
\hline $\begin{array}{c}\text { Degree of } \\
\text { mechanization }\end{array}$ & $\begin{array}{l}\text { Average degree of } \\
\text { mechanization }\end{array}$ & $\begin{array}{l}\text { High degree of } \\
\text { mechanization, } \\
\text { exploiting and } \\
\text { saving labor }\end{array}$ & $\begin{array}{c}\text { Increase in } \\
\text { agricultural } \\
\text { machinery and } \\
\text { equipment }\end{array}$ & $\begin{array}{l}\text { High degree of } \\
\text { mechanization, } \\
\text { adopting saving } \\
\text { labor }\end{array}$ & $\begin{array}{l}\text { Intensiveand large- } \\
\text { scale production of } \\
\text { new technologies } \\
\text { and equipment }\end{array}$ \\
\hline $\begin{array}{c}\text { Production } \\
\text { management level }\end{array}$ & $\begin{array}{l}\text { Mainly productive } \\
\text { labor, supplemented } \\
\text { by managerial labor }\end{array}$ & $\begin{array}{l}\text { Combination of } \\
\text { managerial and } \\
\text { productive labor }\end{array}$ & $\begin{array}{l}\text { Mainly productive } \\
\text { labor, low degree } \\
\text { of organization }\end{array}$ & $\begin{array}{c}\text { Mainly managed } \\
\text { labor,low productive } \\
\text { labor }\end{array}$ & $\begin{array}{l}\text { Managed labor and } \\
\text { production, } \\
\text { comprehensive labor } \\
\text { management }\end{array}$ \\
\hline
\end{tabular}

\subsection{The operation mode of the new agricultural management entity}

The coexistence of multiple new types of agricultural business entities is shown in Figure 1. It shows how can business entities maximize the benefits of agricultural industrialization by improving professional households, family farms, farmer cooperatives, and leading agricultural enterprises. Therefore, the improvement of the agricultural socialized service system and the management level of agricultural leading enterprises provides a strong guarantee for the development of training new agricultural business entities under the rural revitalization. Farmers' use of productivity-enhancing technologies is critical to efforts to promote smallholder market participation ${ }^{5}$. managing high labor production to sales, and commercialization as the target agricultural management organization. It officially appeared in 2012 and the Central No. 1 policy in 2013-2015 File. ZhaoXin Zhang ${ }^{3}$ and others believed that the main body of the new-type agricultural management has greater scale and management system to engage in larger-scale agricultural production. Zuhui Huang ${ }^{4}$ and others believe that with the development of rural reforms, small-scale farmers' family operations have gradually evolved to large-scale operations, and diversified agricultural business entities have emerged.

At present, the classification of new agricultural business entities in my country mainly includes: professional large households, family farms, farmers' cooperatives, agricultural leading enterprises and agricultural socialized services, and comparison of types of new agricultural business entities. As shown in Table 1. management 


\section{Cultivation models of different types of new agricultural management entities}

\subsection{New agricultural entities are cultivated at different levels}

Rongping Ruan 's ${ }^{6}$ data survey from the urgent information of survey demand shows that the main agricultural subjects are agricultural technology promotion, market supply and demand, production and management, and epidemic diseases. These are the most urgent needs of agricultural subjects. They accounted for $27.97 \%, 26.37 \%, 15.43 \%$ and $8.36 \%$, respectively.It can include the following. The agricultural technology is mainly a combination of theory and practice, focusing on the practical problems that farmers urgently need to solve.It can be such as the prevention and control of plant diseases and insect pests, rice cultivation techniques, wheat fertilization and spraying, maintenance of flower cultivation and high-yield transformation techniques. The instructor is a professional and technical person, and the knowledge points are accurate and authoritative, and the teaching material produced by the training teacher is required for the training period, so that the agricultural subject can understand it at a glance, and understand it at a glance.The use of multimedia is that the classroom with pictures and texts can bring freshness and interest to the agricultural subjects. More importantly, it enhances the intuitive acquisition of knowledge in agricultural lectures, and greatly improves the real-time operation ability of farmers' training.Management type, the current research on farmers' behavior is mainly from the amount of farmland input factors, the degree of part-time operation, the scale of production and the transfer of farmland.Some scholars have conducted research on the allocation of farmers' time.The comprehensive agricultural development type is mainly to improve the comprehensive agricultural production capacity, the strategy for the construction of modern demonstration areas and the expansion of comprehensive agricultural development projects.Adhering to the goal and strategy of the comprehensive benefits of comprehensive agricultural development is the birth, development, and change process of comprehensive agricultural development, as well as the successful experience of inheriting and promoting comprehensive agricultural development.Marketing-based, professional marketing strategies can help farmers reduce investment in agricultural sales to maximize profits, such as product processing strategies, quality and safety strategies, price strategies, brand building strategies, promotional strategies, and strategies for broadening sales channels.

Ning Yuan ${ }^{7}$ and others believe that mechanized farming is conducive to increasing agricultural labor productivity, increasing unit yield and total output, reducing the cost of agricultural products, and narrowing the gap between industry and agriculture .New-type agricultural subject vocational technical training will improve farmers' non-agricultural employment ability and provide technical support for farmers to choose different employment channels ${ }^{8}$ To learn new technologies to optimize the reasonable allocation of resources, and the market as a guide, it should be cultivated in accordance with the requirements of professional, intensive, and large-scale modern agricultural production and operation. It can be cultivated according to the needs of different levels. The specific content is mainly shown in Figure 2.Among them, A: land, labor and capital, B: agricultural technical expertise, $\mathrm{C}$ : business management, D: market supply and demand marketing, $\mathrm{M}$ : Information management technology, N: Opportunity and demand, P: Technical industry support. The cultivation of new agricultural business entities mainly uses advanced science and technology such as information, farming, and breeding.

\subsection{Factor allocation is optimized}

The establishment of a sales market with professional technology is more conducive to the development of the agricultural industry chain. Opportunities and needs, insight into the market direction, management transformation, optimization of the allocation of modern production factors, participation in socialized division of labor management, specialized production, and largescale modern agricultural production organizations. Comprehensive agricultural development has created technological conditions for improving comprehensive agricultural production capacity ${ }^{9}$.

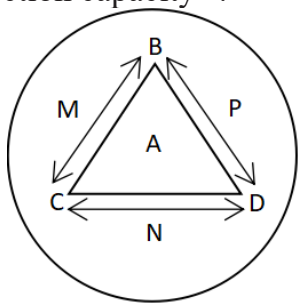

Figure 2 Optimization of main factor allocation of new agricultural management

\section{Technical framework selection}

"Internet + " education can be combined with the current structural needs of new agricultural business entities, and can provide training for new agricultural business entities to adapt to the future development direction of agricultural mechanization.Limin $\mathrm{Lu}{ }^{10}$ and others believe that "Internet +" has had a revolutionary impact on rural vocational education and training. Xiaohe $\mathrm{Ma}^{11}$ believes that rural industry integration is based on agriculture, expanding the scope of industries and increasing farmers' income.Industrial integration is a typical feature of modern industrial development. With the support of economy and technology, the industry has expanded its extension. The Internet industry has the characteristics of strong integration and high relevance. These two characteristics just determine the inevitability of its integration with other industries.At present, the main purpose of the integration of agriculture and other industries is to extend the industrial chain of agriculture 
itself, expand the industrial scope of agriculture, and realize the cluster of various industries. When this goal is achieved, it will improve the economic benefits of the agricultural industry, and at the same time promote the development and progress of other industries.

Establish a comprehensive agricultural resource database to provide users with a query for information needs to master the latest agricultural technologies. Liling Zhao ${ }^{12}$ believes that the "Internet + " agriculture is closely linked to realize the sharing of agricultural production information and reduce agricultural production and transaction costs. You need to build a Web project, use Eclipse as the development tool, select MySql as the database, and the version is community-8.0.15.0. The framework uses SSM (Spring + Spring MVC + MyBatis) to fully support all functions of the database, which is convenient for development. Xiaobei $\mathrm{Wei}^{13}$ and others believe that the application of "Internet + " and modern technology "smart agriculture" has become an important driving force for the upgrade of the entire agricultural industry chain.

\section{Conclusion}

This article comprehensively summarizes and analyzes the concepts, types, characteristics and training modes of new agricultural management subjects. The main body of the new type of agricultural operation is still in the primary stage, facing problems such as asymmetry in technical information, difficulties in professional planting technology, and low management level. In response to these problems, it is not only necessary to continue to develop and improve itself through education and training, and to improve the core competitiveness of regional agricultural products. Regarding these issues of new agricultural subjects, education and training themselves need to be continuously developed and improved to improve the core competitiveness of regional agricultural products. The main body of the new type of agricultural operation shall follow the modern agricultural production and operation management model of specialization, intensive, large-scale and marketization. The new type of agricultural operation entity has truly become a new type of agricultural operation entity that understands technology, is good at management, and can manage. At the same time, it also needs the help and support of the government, enterprises and other departments to support the development of new agricultural management subjects and promote the rapid development of new agricultural management subjects.

\section{References}

1. Zhaoxin Zhang. The plight of the new-type agricultural management subject and its institutional innovation [J]. Reform, 78,87(2013)

2. Zuhui Huang, Fu Yuzhi, Xu Xuchu. Analysis of the efficiency and influencing factors of farmers' professional cooperatives[J]. China Rural Economy, 4,13(2011)

3. Olwande, J, Smale, M.Mathenge, M.K.Place, F\&Mithofer, D.Agricultural marketing by smallholders in Kenya A comparison of maize, kale and dairy[J]. Food Policy,22,32(2015)

4. Rongping Ruan, Pei Zhou, Fengtian Zheng. The development status and countermeasures of new agricultural management informatization under the background of "Internet+" - Based on the survey data of 1394 new agricultural management [J]. Management World, (2017)

5. Yuan Ning, Liu Xiaochuan. An Empirical Study on the Influence of Different Cultivated Land Scales on Farmers'Food Management Behaviors[J].Research World,33,36(2013)

6. Jianliang Nie, Zhangbao Zhong. The influence of the degree of household differentiation on the behavior and scale of farmland transfer[J].Resources Science,91,99(2014)

7. Liangui Han, Yan Wang. Study on the Objective, Strategy and Feasibility of Comprehensive Agricultural Development and Management in the New Period[J].Economic Research, 3,67(2018)

8. Limin Lv,Xinyue Ma. Policy Support for Vocational Education and Training of New Generation Farmers in the "Internet + " Era[J]. Vocational and Technical Education,63,67(2018)

9. Xiaohe Ma. Promote the deep integration of rural primary, secondary and tertiary industries $[\mathrm{J}]$. China Cooperative Economy, 9,10(2016)

10. Liling Zhao. Research on Information Sharing Strategy of Agricultural E-commerce Based on "Internet $+"[\mathrm{~J}]$. Business Economics Research, $111,114(2019)$

11. Xiaobei Wei. Miao Wang. The whole industry chain model promotes the upgrading of agricultural industry under the background of "Internet + "[J]. Shandong Social Sciences, 167,172(2018) 